\title{
HOW BRAVE CAN WE BE? THE CITY AS A POLITICAL EXPERIMENT
}

\author{
Krzysztof Nawratek
}

Cities are political and their spaces are political from Egypt to Turkey, from Brazil to Ukraine, new political movements appear on squares and on streets. Cities are also political, because they are key nodes of contemporary global capitalism. However, in recent years mainstream architecture and urbanism has drifted away from any kind of political engagement, because of the logic of TINA (There Is No Alternative) architects were forced to become just 'cogs' in the neoliberal socio-economic machine. They were expected to produce colourful pictures of funky buildings to please consumers, lend clients an image and in turn secure capital investment. However, the financial crisis of 2008 created cracks in this logic and opened up the possibility of re-introducing a political and socio-political agenda for architecture and urbanism. Architecture is a creative discipline, but for some years now the architects 'use' of creativity was often limited to new technology. Yet, the financial crisis has presented a much wider spectrum of possibilities and architects can now (again!) engage with socio-political and economic issues. Several projects presented at the Venice Biennale 2012 (for example the USA pavilion and "Working with the $99 \%$ " project by ateliermob) and also several recent books (for example "Spatial Agency. Other ways of doing architecture" by Nishat Awan, Jeremy Till and Tatjana Schneider or "The Possibility of an Absolute Architecture" by Pier Vittorio Aureli) show, in very different ways, new paths for the future - the architecture of engagement - social, political and economic. The focus of the "City as a Political Space" issue of the Journal of Architecture and Urbanism is on aspects of architecture and urbanism that critically and creatively experiment with new socio-political and economic models.
Matthew Gierszon writes about the architecture of Walter Segal, pointing to the possibility of preserving the modernist ethos based on the idea of social progress, while rejecting the authoritarian, top-down model that was dominant in modernist practice of the $20^{\text {th }}$ Century. Contemporary architects-activists could be perceived as dissidents of the modern movement. For them, one of the key aspects of architecture is its ability to create common space, and the notion that 'proper' modernist architecture must be produced by a community. Community is also at the center of interest for Cristina Bianchetti and Angelo Sampieri. They are convinced that community is a progressive value, worthy of building on and protecting even when it is based on conservative nostalgia. Krzysztof Nawratek however, takes a different position; he argues that new, experimental spaces (which in his text he calls 'Taubesian places') must be built if the world is to survive. Using Carl Schmitt's Partisan figure he argues that a 'Taubesian place' could be created and protected on any scale by any element of power structure willing to mediate between regular/legal and irregular/unknown. Sally Carlton analyses in detail the municipal election campaign in Christchurch (New Zealand), pointing to the importance of the presence of certain images (and imagination) in a physical city space. Politics is always about the promise of a different world - this promise must be seen to be successful. Hamed Khosravi indicates a radically political (in terms used by Carl Schmitt) dimension to the Persian city - both in the Islamic and pre-Islamic tradition. Ioana Popovici examines architectural competitions in Stalinist Romania to demonstrate dissident, hidden currents in the Romanian architecture of that time. Even authoritarian regime can't fully impose hegemonic 
ideological narrative. Peter Marcuse argues for public spaces as being rather an action, not just a form. Public spaces should challenge any anti- (or just a-) democratic paradigm - even if this paradigm is legal and accepted by the majority. Jonathan Vickery ponders the chances of the existence of a politically engaged urban gallery using the example of Eastside Projects.

Papers included in this issue may be read individually, but it seems that it is only in the context of others that they truly reveal their hidden meaning and significance. This conversation between texts was intended, the authors did not have contact with each other, and didn't know what each other's papers would be about. We can observe here a similar mechanism that works in the city - every building, street or district can only be fully understood and appreciated in the context of other buildings, streets and districts. The city is a political space, because it is a continuous process of negotiation of different, distinct narratives. This is not Carl Schmitt's politics; this is not so much about conflict, but rather about negotiations and repeated attempts to tell - an always different - universal story. We need to learn from the city to build a better world, with better, more just and more democratic politics. 